\title{
The Religion of Protestants
}

The Church in English Society 1559-1625: Ford Lectures 1979

\section{Patrick Collinson}

This book takes the form of a series of studies of the constituent elements of post-Reformation ecclesiastical and religious life: crown, bishops, clergy, magistrates, and people. A concluding chapter investigates the large measure of voluntary and semi-private religious activity in early Stuart England.

$£ 17.50$

\section{Thomas Chalmers and the Godly Commonwealth in Scotland}

\section{Stewart J. Brown}

Thomas Chalmers, the Scottish Evangelical social reformer and ecclesiastical politician, is best known for his role in the Disruption of 1843 . This biography traces his conversion to a traditional Christian commonwealth ideal and his subsequent efforts to adapt this ideal to the social conditions of an industrializing nation. £25

\section{St John's Gospel}

\section{A Commentary}

\section{R. H. Lightfoot, edited by C. F. Evans}

This book is addressed to those who wish to make a serious study of the Bible but may not have any special linguistic equipment such as a knowledge of Greek. It is primarily a religious and theological exposition of the text of St John's Gospel. First published in 1956, it is now available in paperback. £7.50

\section{Cyril of Alexandria - Select Letters}

\section{Edited by Lionel R. Wickham}

Cyril, bishop of Alexandria from 412 to 444 , was in some ways the most influential of all the classic Greek fathers. In Christology all subsequent writers have had to take account of him whether as model or adversary. This book reveals the reasons for his influence. $£ 15$

\section{Oxford University Press}




\section{NOTES FOR CONTRIBUTORS}

I. Contributions and books for review should be sent to the Editor, Professor H. D. Lewis, King's College, Strand, London, wC2R 2LS.

2. Articles submitted to the journal should in general be between 5,000 and I 0,000 words long, though articles outside these limits will be acceptable if there is some good reason for their exceptional length or brevity. Articles in two or more parts may occasionally be accepted provided each part is independently intelligible. They should normally be in English.

3. Submission of an article is taken to imply that it has not previously been published, or is not being considered for publication elsewhere.

4. Contributions should be clearly typed in double spacing, preferably on $\mathrm{A}_{4}$ paper, with a wide left-hand margin. The typescript should be prepared to accord as closely as possible with the typographical conventions of the journal.

5. Footnotes should be used sparingly: in general, to give sources of direct quotations, references to main authorities on disputable questions, and evidence relied on for a new or unusual conclusion. They should be numbered in one sequence throughout the article, and should preferably be typed in double spacing at the end of the article.

6. Contributors should keep one copy of the typescript for correcting proofs.

7. First proofs may be read and corrected by contributors provided that they can give the Editor an address through which they can be reached without delay and can guarantee to return the corrected proofs to the Editor, by airmail where necessary, within ten davs of receiving them.

8. Correction should be kept to an asousue ninimum. It should be confined to errors of the typist or printer unless the Editor authorises otherwise.

9. All contributors of articles receive 50 free offprints. Reviewers will receive five or more offprints of their reviews.

10. If rejected manuscripts are to be returned, stamps or international coupons should be sent to cover postage, but it would normally be simpler just to retain a copy.

11. Contributors of accepted articles will be asked to assign their copyrights, on certain conditions, to Cambridge University Press, to help protect their material, particularly in the USA. 


\section{Religious Studies}

Volume $19 \quad$ Number $3 \quad$ September 1983

\section{GONTENTS}

DANIEL, SIR GORONWY

The Relevance of the Christian Message

page 281

TRIGG, ROGER

Religion and the Threat of Relativism

TRETHOWAN, ILLTYD

The Significance of Process Theology

SURIN, KENNETH

Revelation, Salvation, the Uniqueness of Christ and

Other Religions

DOORE, G. L.

Religion within the Limits of the Quest for the Highest

Good

FERREIRA, M. JAMIE

Newman and the 'Ethics of Belief'

MARUF, MOHAMMED

Iqbal's Concept of God: An appraisal

SWINBURNE, RICHARD

Mackie, Induction, and God

GOWEN, JULIE

Foundationalism and the Justification of Religious Belief

GORDON, DAVID

Is the Argument from Evil Decisive?

Review Article

WILLIAMS, GYRIL G.

Studies in Methodology

Reviews

(C) Cambridge University Press 1983

CAMBRIDGE UNIVERSITY PRESS

The Pitt Building, Trumpington Street, Cambridge CB2 IRP 32 East 57 th Street, New York, N.Y. 10022

Religious Studies is indexed in the Religion Index One: Periodicals

Printed in Great Britain at the

University Press, Cambridge 